\title{
Title: Multiple Potential Roles for B cells in Atherosclerosis
}

\author{
Running title: B cells and Atherosclerosis
}

\section{Andrew P Sage ${ }^{1}$ and Ziad Mallat ${ }^{1,2, *}$}

${ }^{1}$ Division of Cardiovascular Medicine, Department of Medicine, University of Cambridge, Cambridge, UK, ${ }^{2}$ Institut National de la Santé et de la Recherche Médicale, Unit 970, Paris Cardiovascular Research Center, 75015 Paris, France

*Corresponding author. Address : British Heart Foundation Laboratory of Cardiovascular Medicine, West Forvie Building, Robinson Way, Cambridge, CB2 0SZ.

Email: zm255@medschl.cam.ac.uk 


\begin{abstract}
The development of atherosclerosis is the major etiological factor causing cardiovascular disease and constitutes a lipid-induced, chronic inflammatory and autoimmune disease of the large arteries. A long standing view of the protective role of B cells in atherosclerosis has been challenged by recent studies using B cell depletion in animal models. Whereas complete B cell deficiency increases atherosclerosis, depletion of B2 but not B1 cells reduces atherosclerosis. This has led to a reevaluation of the multiple potential pathways by which B cells can regulate atherosclerosis, and the apparent opposing roles of B1 and B2 cells. B cells, in addition to having the unique ability to produce antibodies, are now recognized to play a number of important roles in the immune system, including cytokine production and direct regulation of $\mathrm{T}$ cell responses. This review summarises current knowledge on B cell subsets and functions, and how these could distinctly influence atherosclerosis development.
\end{abstract}




\section{Introduction}

Cardiovascular disease remains a leading cause of death in the developed world and is growing in prominence worldwide, with $80 \%$ of cardiovascular deaths now occurring in low-middle income countries (1). Atherosclerosis constitutes a lipid-induced, chronic inflammatory and autoimmune disease of the large arteries (2-5), and is the major underlying cause of heart disease and stroke. Control of cholesterol and blood pressure are effective preventive therapies, however further demand remains to better target vulnerable, event-inducing plaques, or alternatively reduce development of vulnerability. Reducing the associated chronic inflammation sustaining the immune response is an important target for scientific and future therapeutic investigation. Despite a long known association with atherosclerosis, B cells and antibodies have not always been a research focus. Current knowledge from the immunology field defines diverse functions for B cells beyond antibody secretion, with multiple subsets playing a role in both innate and adaptive immunity. This, in combination with results from mouse models suggesting different types of B cells can enhance as well as protect from atherosclerosis, has reignited interest in how these abundant and multifunctional cells impact all stages of atherosclerosis development. This review first describes B cell subsets and functions, then summarises current views on the potential roles of B cells in atherosclerosis and future targets for research that could enable therapeutic targeting.

\section{$B$ cell subsets and functions}

B cell development and the different B cell subsets characterized are reviewed in detail elsewhere (6-8). Broadly, B1 and B2 cells constitute the major 2 groups of B cells and can be considered part of the innate and adaptive immune systems, respectively. B2 cells develop in the adult bone marrow from hematopoietic stem cells through a well-characterized series of precursor stages (7), whereas at least some B1 cells develop in the fetal liver and are self-sustaining in the adult independently of HSCs $(9,10)$ (Figure 1A). B cells are primarily found in secondary lymphoid organs (spleen and lymph nodes), blood and submucosa of the intestine and lung, but also adipose tissue, aortic 
adventitia and sites of inflammation (11). The primary and unique characteristic of B cells is the expression of surface antibody, or B cell receptor, and thus their major function as the source of antibody-producing plasma cells. Each B cell clonal lineage develops a unique B cell receptor through somatic genome rearrangement of the multi-gene immunoglobulin locus. The binding specificity and affinity of the B cell receptor to self or foreign antigen defines the fate of each B cell. In the steady state, a system has evolved that provides a repertoire depleted of highly autoreactive clones yet robust and diverse enough to target the multitude of potential antigens encountered. Thus, multiple checkpoints regulate developing B cells to hone the B cell repertoire through mechanisms including receptor editing, anergy and apoptosis $(12,13)$. In addition to antigen, important regulators of B cell development and activation include B cell activating factor (BAFF), and a proliferationinducing ligand (APRIL) (14). BAFF is essential for B2 cell maturation beyond the Transitional-1 (T1) stage in the spleen through interaction with BAFF receptor (BAFFR) (15-17). BAFF can also regulate survival, activation and function of both B1 and B2 cells through BAFFR and the alternative receptor TACI (transmembrane activator and calcium modulator and cyclophilin ligand interactor). APRIL is a BAFF homologue but interacts only with TACI and a third receptor BCMA (B cell maturation antigen), but not BAFFR. TACI is upregulated in activated B cells and plays complex roles in B cell proliferation, survival and antibody class switching (18-20) whereas BCMA is upregulated on plasma cells and is essential for plasma cell survival in the bone marrow by transducing APRIL signals in the plasma cell niche $(21,22)$.

B1 cells play a major role in maintaining the barrier function of mucosal surfaces and possess B cell receptors with germline-encoded specificities for common pathogen-associated epitopes and rarely undergo B cell receptor editing or maturation, thus are as much part of the innate as the adaptive immune system. B1 cells are the source of natural antibodies, which are produced independently of any external antigens. One major family of these epitopes are oxidation-associated epitopes and include phosphorylcholine (PC) and malondialdehyde (MDA) (23). Such epitopes are common in 
endogenous debris such as apoptotic and necrotic cells and modified lipoprotein particles, e.g. oxidized low density lipoprotein (oxLDL). Thus, natural antibodies (and other antibodies targeting these antibodies) play an important role in homeostatic clearance of dead cells and other debris including oxLDL, and may contribute significantly to clearance pathways in atherosclerosis. Mature B2 cells recirculate via the blood through secondary lymphoid organs where they may encounter antigens captured and displayed by macrophages and dendritic cells, in general as part of immune complexes with (presumably) low affinity, natural or previously produced antibodies. Depending on other signals and the precise location, B2 cells are then activated and proliferate, leading variously to short-lived plasma cells, long-lived plasma cells that migrate to the bone marrow and memory B cells that enable life-long immunological memory and more rapid responses upon subsequent antigen encounters (24) (Figure 1A). Bone marrow plasma cells can persist for years and continue producing antibodies, but re-exposure to the same antigens stimulates memory B cell activation and formation of new plasma cells. Marginal zone B2 cells bridge the functions of B1 and follicular B2 cells, possessing somatically rearranged B cell receptors but having a memory-like phenotype that allows a more rapid B1-like response that can be activated by innate signals like Il-5 or toll-like receptor ligands. In addition to developmental antibody receptor diversification, mature B2 cells selected and activated by the presence of cognate antigen undergo two further changes to their B cell receptor (antibody) - class switching of the Fc region and mutagenesis of the antigen binding Fab region to enhance affinity. Affinity maturation occurs in proliferating activated B cells in the germinal centers (GC) of secondary lymphoid organs where higher affinity clones prevail through competition for antigen immobilized on follicular dendritic cells (25).

Antibodies play a primary effector function in neutralizing and clearing pathogens, pathogenassociated molecules and infected cells through a range of mechanisms, including antibodydependent cellular cytoxicity, recruitment of the complement system and promoting phagocytosis 
(26-28). Antibodies also influence innate immune function and phenotype, particularly macrophage inflammatory activation through the Fc region binding to Fc receptors on the cell surface (26). B cells, like most immune cells, produce a range of cytokines with potent and diverse effects. For B cells, these include most prominently Il-6, Il-10 and TNF (29). B cells also respond to many cytokines including Il-6, TNF, IFN- $\alpha$, Il-4, Il-5, and IFN- $\gamma$. More recently, a distinct subset of spleen B cells has been shown to be capable of GM-CSF production and that these cells can significantly influence innate immune functions (30). Alternatively, B cell derived MCP-3 (Cc17) is critical to monocyte mobilization in response to myocardial infarction with B cell depletion leading to reduced infarct area and improved heart function (31).

B cells also regulate their adaptive immune counterparts, $\mathrm{T}$ cells, through antigen presentation and co-stimulation (32). In general, B cells are not phagocytic like myeloid antigen presenting cells, and only antigen endocytosed while bound to the B cell receptor (surface antibody) is processed and presented on B cell MHCII molecules to helper CD4+ T cells. Although dendritic cells act as primary activators of helper T cells, in many cases B cell - helper T cell interactions are critical in sustaining and regulating the nature of both $\mathrm{T}$ cell and $\mathrm{B}$ cell responses, for example in response to lower antigen levels (33).

Not all B cells require the presence of cognate antigen or the presence of helper T cells for their activation and differentiation into plasma cells. B1 cells and certain B2 cell subsets, such as marginal zone B cells, can be activated directly by pathogen-associated molecular patterns, for example tolllike receptor ligands, or cytokines such as IFN- $\alpha$, Il-1 $\beta$ and Il-5 $(34,35)$. In contrast, responses to protein antigens are commonly $\mathrm{T}$ cell dependent and require ongoing contact with antigen, costimulation and cytokines; the latter two signals received from specialized follicular helper T cells. BAFF and APRIL also play prominent roles in B cell activation in addition to being critical to homeostatic maintenance $(16,17,36)$. Thus, both innate and adaptive immune pathways could lead to B cell activation in atherosclerosis (Figure 1B). 


\section{Association of $B$ cells and autoantibodies with atherosclerosis}

The humoral nature of B cell antibody responses suggests a remote regulation of atherosclerosis is most likely and most important. Furthermore, a number of other remote pathways negate a need for the presence of B cells within or adjacent to plaques for them to be important. These include T cell responses in spleen and lymph node, regulation of innate cell differentiation, monocyte mobilization from bone marrow, and their presence at alternative sites of cardiovascular disease-associated inflammation such as adipose tissue. Nevertheless, B cells can be found in plaques but are more often found at adventitial sites close to plaques (37-39). Initial reports suggested these cells may be plasma cells, whereas a recent report concluded that these B cells are most likely B2-derived plasmablasts, with evidence of local affinity maturation occurring in both adventitia and plaque, and the presence of a limited number of class-switched clones (40). The adventitia is a well-recognised site for immune responses (41), and advanced human and mouse atherosclerosis leads to the development of tertiary lymphoid organs in the adjacent adventitia $(38,42)$. This suggests a potential for local B cell responses in advanced human atherosclerosis and thus ongoing regulation of plaque status. Whether adventitial immune responses and cell accumulation also occur in symptomatic coronary and carotid plaques is unclear, however it is easy to envisage aorta-originating B cell and T cell responses regulating plaques at other sites. Very recently, a study examining whole blood global gene co-expression identified a strong indication of B cell dysregulation in coronary heart disease patients compared to controls (43) and another showed activated CD86+ B cells associate with a higher risk of stroke (44).

The presence of antibodies within atherosclerotic plaques is much more prominent than B cells themselves, with abundant $\operatorname{IgM}$ and $\operatorname{IgG}$ detected in human and mouse plaques $(39,45,46)$.

Circulating levels of modified LDL-reactive antibodies also associate with atherosclerosis $(47,48)$, as do those to heat shock protein 65 (49). Levels of both natural IgM antibodies and adaptive IgG antibodies reacting with moieties found in modified LDL and on apoptotic cells, e.g. phophocholine 
or malondialdehyde, are associated with atherosclerotic burden in many studies, although not all (50-52). Interestingly, IgM levels decline with age (53), consistent with studies showing an inverse correlation with disease and extensive experimental evidence of its protective influence $(46,54)$. Overall, the prevailing view is that anti-oxLDL IgG is positively correlated whereas $\operatorname{IgM}$ is negatively correlated; however doubt still remains, particularly in the case of IgG. Equally, prospective studies have shown mixed results (52). For example, anti-modified LDL antibodies predicted myocardial infarction in type II diabetes patients in the VADT study (55), but there was no prognostic value in the EPIC-Norfolk study (56). A further impact of B cells on atherosclerosis is the association of other autoimmune diseases such as rheumatoid arthritis (RA), systemic lupus erthyramatous and Sjorgren's syndrome $(57,58)$ with an increased risk of cardiovascular disease. How the presence of these autoimmune diseases influences cardiovascular disease is complex, but cross-reactivity of autoantibodies is one contributory mechanism as well as systemic proinflammatory cytokines that may be induced in part dependently on autoantibodies. In RA, the correlation between oxLDL IgG antibodies and atherosclerosis seems more consistent (59-61). Recently, in SLE patients, levels of autoantibodies to dsDNA and Cardiolipin were associated with higher levels of noncalcified plaques, potentially more prone to rupture (62) and a previously unappreciated pro-atherosclerotic role for IgE antibodies was demonstrated in $\mathrm{ApoE}^{-/-}$mice (63). The functional roles and overall influence of antibodies in atherosclerosis are further discussed below.

\section{B cells regulate atherosclerosis - Evidence from mouse models}

Given the diverse functions and wide ranging impact of B cells on immune responses, it is unsurprising that B cell regulation of atherosclerosis is complex to dissect. Past studies suggesting a solely protective role for B cells in atherosclerosis must now be reinterpreted based on the divergent roles of different B cell subsets and their antibodies. The increased atherosclerosis in B cell-deficient ( $\mu \mathrm{MT})$, atherosclerotic-prone ApoE $\mathrm{E}^{-/-}$mice (64) and splenectomized mice (65) could be primarily 
due to the lack of B1 cells and natural $\operatorname{IgM}(46,54)$, which plays a prominent role in opsonisation and non-inflammatory removal of oxLDL as well as apoptotic cells. In contrast to genetic deficiency of all B cells, anti-CD20 antibody treatment, which preferentially depletes B2 cells, leaving B1 cells largely intact, reduces atherosclerosis $(66,67)$. Corroborating these studies, the specific lack of mature B2 cells in ldlr ${ }^{--}$mice transplanted with B cell activating factor receptor (BAFFR)-deficient bone marrow reduces atherosclerosis (68). The same is true for $\mathrm{BAFFR}^{-/-}$mice on the $\mathrm{ApoE}^{-/-}$ background (69) and B cell-specific BAFFR deficiency (68). Resupplementation of B cell-deficient mice with spleen B2 cells reverses the reduction of atherosclerosis (67). However, other groups have shown protective effects of transferred spleen B cells $(65,70)$, suggesting as yet unclear complexities and multiple potential mechanisms for B2 cell regulation of atherosclerosis. Doran et al (70) showed that the ability to home to the aorta through CCL20-CCR6 signaling was key for atheroprotection. It is not clear if this property was important to recruit a certain subset or to the localization of B cells in general to the adventitia. Further fractionation of B2 (or spleen) subsets, or transfer of B cells from appropriate knockout mice, will be necessary to determine these remaining questions.

\section{Mechanisms for $B$ cell regulation of atherosclerosis}

There are 3 major modalities by which B cells could influence atherosclerosis, 1) through antibodies, 2) through regulation of $\mathrm{T}$ cell responses via cell-cell contact, and 3) through production of cytokines. These different modalities may act through a variety of pathways and each has both antiand pro- atherogenic potential.

\section{1) Multiple roles of antibodies in atherosclerosis}

Past studies have provided many useful insights into the potential roles for autoantibodies in atherosclerosis. However, the lack of complete discrimination between natural or innate-derived and adaptive antibodies, the use of immunization strategies that also stimulate natural antibody and regulatory T cell-mediated immune responses (71), and a focus on oxLDL targeting antibodies (72), 
means that the overall influence of B cell antibodies is still unclear. The most recognized and studied autoantigen in atherosclerosis is modified LDL, with epitopes from various forms targeted both by natural antibodies and B2 cell-derived, class-switched IgG antibodies. Hsp60 and 65, as well as $\beta 2$ glycoprotein I, are further autoantigens (73). Passive Ig transfer (intravenous immunoglobulin; IVIg) suppresses atherosclerosis (74). IVIg, used in other autoimmune diseases and transplant patients, is hypothesised to work through differential sialylation of the Fc portion, leading to immunosuppressive pathways via IL-33, Il-4 and induction of macrophage Fc $\gamma$ RIIb (75) as well as through induction of regulatory T cells (76). Although a number of modified LDL or apoB peptide based active immunization strategies consistently reduce atherosclerosis $(77,78)$, their effects are primarily due to increased regulatory $\mathrm{T}$ cell responses, enhanced natural antibody production and a shift to Th2 IgG responses, thus may not represent endogenous humoral responses $(71,79)$. Indeed, both immunogenic adjuvant-containing $(77,78)$ and tolerogenic (e.g. mucosal or oral) formulations $(79,80)$ lead to enhanced Treg levels and reduced atherosclerosis. In contrast, immunization with Hsp65 can enhance atherosclerosis (81-83), whereas tolerogenic strategies targeting Hsp65 reduce atherosclerosis (84-86). Immunization against $\beta 2$-GPI can also enhance atherosclerosis (87). The consequences of endogenous antibody responses are far better understood for IgM antibodies than IgG and other isotypes, as exemplified by the E06 monoclonal phospholipid-reactive $\operatorname{IgM}(88)$. It is likely that enhanced clearance of oxLDL, preventing its accumulation in plaque and foam cell formation, is a major mechanism for the action of $\mathrm{B} 1$ cell derived $\operatorname{IgM}(89)$. Interestingly, very recent data suggests that excessive $\operatorname{IgM}$ accumulation in plaque bound to necrotic and lipid debris could in fact be pro-inflammatory (90), emphasising the need for further investigation. A major effector pathway for IgG antibodies linked to atherosclerosis are the Fc $\gamma$ receptors, of which there are both pro-inflammatory activating receptors (I, IIa, III and IV) and an inhibitory receptor (IIb) $(26,91)$. A pathogenic role for $\operatorname{IgG}$ antibodies/immune complexes in atherosclerosis is supported by findings that mice lacking activating, pro-inflammatory Fcy (IgG) receptors have reduced 
atherosclerosis $(92,93)$, whereas mice lacking the inhibitory Fc $\gamma \mathrm{RIIb}$ have enhanced atherosclerosis (94). Immune complexes are known to activate macrophages (95), a central mediator of plaque formation via Fc receptors, and oxLDL immune complexes can promote foam cell formation. Different IgG isotypes have varying affinities for Fc receptors and thus different activatory capacity, for example $\mathrm{IgG} 2 \mathrm{a} / \mathrm{c}$ (different strains express a or c isoforms) in mice is highly activatory (26). IgG2c is mainly induced in association with Th1 type responses such as those which dominate atherosclerosis, accordingly anti-oxLDL IgG2c is commonly found in atherosclerotic mice $(46,66,68,92)$. In addition, the pathogenic or protective role of the targeted antigen (e.g. oxLDL vs heat-shock proteins) could strongly influence the effects of humoral responses against it, i.e. targeting the clearly pro-atherogenic oxLDL autoantigen may well be protective, whereas endogenous responses to distinct autoantigens may in contrast be pathogenic. Thus, the consequences of endogenous $\operatorname{IgG}$ responses in atherosclerosis remain ill-defined and methods to specifically target them must be developed to improve our understanding.

\section{2) $B$ cell regulation of atherogenic $T$ cells}

Results from B2 cell depletion models (66-68) support a role for B2 cell potentiation of proatherogneic CD4+ T cell effector responses. Each of these studies was associated with significantly reduced numbers of $\mathrm{T}$ cells in plaques as well as systemic decreases in pro-atherosclerotic IFN- $\gamma$ producing T cells, whereas complete B cell deficiency results in enhanced plaque T cell levels (65). These B cell-deficient ( $\mu \mathrm{MT}$ ) mice have defective Th2 (Il-4) differentiation capacity due to an effect on DCs (96), which may partly be due to lack of antibody-mediated uptake and lysosomal targeting (97). B cell depletion therapy is also effective in reducing other T cell dependent chronic diseases such as multiple sclerosis and rheumatoid arthritis (reviewed in (98)). Conventional CD11 $\mathrm{c}^{\text {hi }}$ dendritic cells are now recognised as the primary and non-redundant antigen presenting cells activating, as well as maintaining, naïve T cells. However, macrophages and B cells can also play prominent roles in presenting antigen to effector T cells and influencing the nature (Th1, Th2, Th17, 
Treg), power and longevity of effector T cell responses (98). It has not yet been investigated whether MHCII-mediated antigen presentation by B cells is important for their stimulation of pro-atherogenic CD4+ T cell responses. Co-stimulatory molecules such as CD40 and OX40, or cytokines like TNF or IL-6 are also likely candidates for future investigation. A recent study investigating RP105, a TLR receptor regulator, also supports an important role for TLR-mediated regulation of B cells in atherosclerosis (99).

\section{3) B cell-derived cytokines and atherosclerosis}

Kyaw et al (67) showed that transferred B2 cells promoted atherosclerosis in T cell (and B cell)

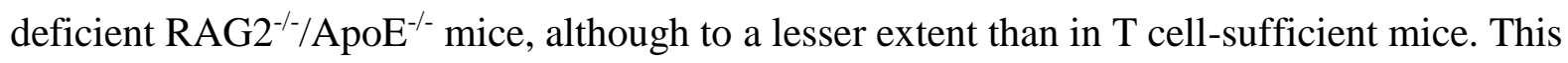
suggests there are both $\mathrm{T}$ cell dependent and independent mechanisms involved. Beyond antibodies, B cells are now recognised to modulate immune responses, particularly those initiating in the spleen, through cytokines. For example, B cells are a major source of $\mathrm{MCP}-3(\mathrm{Ccl} 7)$ in response to myocardial infarction and promote heart injury through monocyte mobilization into the infarct site (31). Although not yet investigated in atherosclerosis, GM-CSF+ B cells, also characterized as B1like plasmablasts resident in the spleen marginal zone, could potentially play an important role in atherosclerosis. In contrast to these potentially pro-atherogenic B cells, Il-10 producing B cells are likely protective. Although rare 'regulatory' B cell subsets characterized by high CD1d, CD19 and CD5 expression are important IL-10 producers (also called B10 cells) (32), other groups suggest that more common B cell subsets including marginal zone and B1 cells may potentially produce IL-10 given the correct environmental stimuli, such as TLR ligands (35). Indeed, switching B cells between Il-10 and Il-6 production is associated with functional regulation of experimental autoimmune encephalomyelitis (EAE), a model of multiple sclerosis (29). B cells are also reported to express further cytokines such as TNF, which may be important in regulating T cell responses (100). Thus B cell cytokine-mediated regulation of atherosclerosis merits further attention in future studies.

\section{Conclusion}


The characterization of heterogeneity within B cells has led to a better appreciation that B cells can play multiple roles in atherosclerosis, with different subsets playing potentially opposing roles. Recent studies in mice have revealed the source of B cell protective immunity as primarily IgM, strongly supported by numerous clinical studies assessing human circulating anti-oxLDL IgM levels, whereas despite multiple lines of indirect evidence, the jury is still out on the functional roles of IgG and the nature of pro-atherogenic B cell immunity. Current research is focused on determining through which of the distinct functional pathways B cells regulate atherosclerosis development and whether these can be translated into therapeutic strategies. An important question will be how closely the roles of murine B cell subsets match their human counterparts, given various differences in cell and antibody isotype subsets. Therapeutically, the BAFF/APRIL system may be a fruitful area of research; establishing their role in endogenous atherosclerotic B cell (and potentially other immune cell) responses could be important in both understanding the underlying causes and mechanisms, and in therapeutic interventions, since a number of BAFF and APRIL targeting monoclonal antibodies have been developed and are already in clinical trials for cancer and autoimmune diseases. This is further supported by data showing upregulated BAFF and APRIL in human plaques (101) and the association of increased BAFF with myocardial infarction (31). 


\section{$\underline{\text { References }}$}

1. Mendis S, Pekka P, Norrving B. Global Atlas on cardiovascular disease prevention and control. World Health Organization; 2011.

2. Legein B, Temmerman L, Biessen EAL, Lutgens E. Inflammation and immune system interactions in atherosclerosis. Cell Mol Life Sci CMLS. 2013 Oct;70(20):3847-69.

3. Lichtman AH, Binder CJ, Tsimikas S, Witztum JL. Adaptive immunity in atherogenesis: new insights and therapeutic approaches. J Clin Invest. 2013 Jan 2;123(1):27-36.

4. Hansson GK, Hermansson A. The immune system in atherosclerosis. Nat Immunol. 2011 Mar;12(3):204-12.

5. Grundtman C, Wick G. The autoimmune concept of atherosclerosis. Curr Opin Lipidol. 2011 Oct;22(5):327-34.

6. Cancro MP. Peripheral B-cell maturation: the intersection of selection and homeostasis. Immunol Rev. 2004 Feb;197:89-101.

7. Hardy RR, Kincade PW, Dorshkind K. The protean nature of cells in the B lymphocyte lineage. Immunity. 2007 Jun;26(6):703-14.

8. Montecino-Rodriguez E, Dorshkind K. New perspectives in B-1 B cell development and function. Trends Immunol. 2006 Sep;27(9):428-33.

9. Kantor AB, Herzenberg LA. Origin of murine B cell lineages. Annu Rev Immunol. 1993;11:501-38.

10. Duan B, Morel L. Role of B-1a cells in autoimmunity. Autoimmun Rev. 2006 Jul;5(6):403-8.

11. Campbell KA, Lipinski MJ, Doran AC, Skaflen MD, Fuster V, McNamara CA. Lymphocytes and the adventitial immune response in atherosclerosis. Circ Res. 2012 Mar 16;110(6):889-900.

12. Scholz JL, Cancro MP. Resolve, revise, and relax: the 3 Rs of B cell repertoire adjustment. Immunol Lett. 2012 Mar 30;143(1):2-8.

13. Von Boehmer H, Melchers F. Checkpoints in lymphocyte development and autoimmune disease. Nat Immunol. 2010 Jan;11(1):14-20.

14. Liu Z, Davidson A. BAFF and selection of autoreactive B cells. Trends Immunol. 2011 Aug;32(8):38894.

15. Schiemann B, Gommerman JL, Vora K, Cachero TG, Shulga-Morskaya S, Dobles M, et al. An essential role for BAFF in the normal development of B cells through a BCMA-independent pathway. Science. 2001 Sep 14;293(5537):2111-4.

16. Gorelik L, Gilbride K, Dobles M, Kalled SL, Zandman D, Scott ML. Normal B cell homeostasis requires B cell activation factor production by radiation-resistant cells. J Exp Med. 2003 Sep 15;198(6):937-45.

17. Sasaki Y, Casola S, Kutok JL, Rajewsky K, Schmidt-Supprian M. TNF family member B cell-activating factor (BAFF) receptor-dependent and -independent roles for BAFF in B cell physiology. J Immunol Baltim Md 1950. 2004 Aug 15;173(4):2245-52. 
18. Yan M, Wang H, Chan B, Roose-Girma M, Erickson S, Baker T, et al. Activation and accumulation of B cells in TACI-deficient mice. Nat Immunol. 2001 Jul;2(7):638-43.

19. Tsuji S, Cortesão C, Bram RJ, Platt JL, Cascalho M. TACI deficiency impairs sustained Blimp-1 expression in B cells decreasing long-lived plasma cells in the bone marrow. Blood. $2011 \mathrm{Nov}$ 24;118(22):5832-9.

20. Bossen C, Cachero TG, Tardivel A, Ingold K, Willen L, Dobles M, et al. TACI, unlike BAFF-R, is solely activated by oligomeric BAFF and APRIL to support survival of activated B cells and plasmablasts. Blood. 2008 Feb 1;111(3):1004-12.

21. O'Connor BP, Raman VS, Erickson LD, Cook WJ, Weaver LK, Ahonen C, et al. BCMA is essential for the survival of long-lived bone marrow plasma cells. J Exp Med. 2004 Jan 5;199(1):91-8.

22. Huard B, McKee T, Bosshard C, Durual S, Matthes T, Myit S, et al. APRIL secreted by neutrophils binds to heparan sulfate proteoglycans to create plasma cell niches in human mucosa. J Clin Invest. 2008 Aug;118(8):2887-95.

23. Miller YI, Choi S-H, Wiesner P, Fang L, Harkewicz R, Hartvigsen K, et al. Oxidation-specific epitopes are danger-associated molecular patterns recognized by pattern recognition receptors of innate immunity. Circ Res. 2011 Jan 21;108(2):235-48.

24. Tarlinton D, Good-Jacobson K. Diversity among memory B cells: origin, consequences, and utility. Science. 2013 Sep 13;341(6151):1205-11.

25. Good-Jacobson KL, Shlomchik MJ. Plasticity and heterogeneity in the generation of memory B cells and long-lived plasma cells: the influence of germinal center interactions and dynamics. J Immunol Baltim Md 1950. 2010 Sep 15;185(6):3117-25.

26. Nimmerjahn F, Ravetch JV. Fcgamma receptors: old friends and new family members. Immunity. 2006 Jan;24(1):19-28.

27. Haskard DO, Boyle JJ, Mason JC. The role of complement in atherosclerosis. Curr Opin Lipidol. 2008 Oct;19(5):478-82.

28. Carroll MC, Isenman DE. Regulation of humoral immunity by complement. Immunity. 2012 Aug 24;37(2):199-207.

29. Barr TA, Shen P, Brown S, Lampropoulou V, Roch T, Lawrie S, et al. B cell depletion therapy ameliorates autoimmune disease through ablation of IL-6-producing B cells. J Exp Med. 2012 May 7;209(5):1001-10.

30. Rauch PJ, Chudnovskiy A, Robbins CS, Weber GF, Etzrodt M, Hilgendorf I, et al. Innate response activator B cells protect against microbial sepsis. Science. 2012 Feb 3;335(6068):597-601.

31. Zouggari Y, Ait-Oufella H, Bonnin P, Simon T, Sage AP, Guérin C, et al. B lymphocytes trigger monocyte mobilization and impair heart function after acute myocardial infarction. Nat Med. 2013 Oct;19(10):1273-80.

32. DiLillo DJ, Horikawa M, Tedder TF. B-lymphocyte effector functions in health and disease. Immunol Res. 2011 Apr;49(1-3):281-92.

33. Bouaziz J-D, Yanaba K, Venturi GM, Wang Y, Tisch RM, Poe JC, et al. Therapeutic B cell depletion impairs adaptive and autoreactive CD4+ T cell activation in mice. Proc Natl Acad Sci U S A. 2007 Dec 26;104(52):20878-83. 
34. Jordö ED, Wermeling F, Chen Y, Karlsson MCI. Scavenger receptors as regulators of natural antibody responses and B cell activation in autoimmunity. Mol Immunol. 2011 Jun;48(11):1307-18.

35. Gray D, Gray M, Barr T. Innate responses of B cells. Eur J Immunol. 2007 Dec;37(12):3304-10.

36. Mackay F, Schneider P. Cracking the BAFF code. Nat Rev Immunol. 2009 Jul;9(7):491-502.

37. Waltner-Romen M, Falkensammer G, Rabl W, Wick G. A previously unrecognized site of local accumulation of mononuclear cells. The vascular-associated lymphoid tissue. J Histochem Cytochem Off J Histochem Soc. 1998 Dec;46(12):1347-50.

38. Houtkamp MA, de Boer OJ, van der Loos CM, van der Wal AC, Becker AE. Adventitial infiltrates associated with advanced atherosclerotic plaques: structural organization suggests generation of local humoral immune responses. J Pathol. 2001 Feb;193(2):263-9.

39. Zhou X, Paulsson G, Stemme S, Hansson GK. Hypercholesterolemia is associated with a T helper (Th) 1/Th2 switch of the autoimmune response in atherosclerotic apo E-knockout mice. J Clin Invest. 1998 Apr 15;101(8):1717-25.

40. Hamze M, Desmetz C, Berthe ML, Roger P, Boulle N, Brancherau P, et al. Characterization of resident B cells of vascular walls in human atherosclerotic patients. J Immunol Baltim Md 1950. 2013 Sep 15;191(6):3006-16.

41. Moos MPW, John N, Gräbner R, Nossmann S, Günther B, Vollandt R, et al. The lamina adventitia is the major site of immune cell accumulation in standard chow-fed apolipoprotein E-deficient mice. Arterioscler Thromb Vasc Biol. 2005 Nov;25(11):2386-91.

42. Gräbner R, Lötzer K, Döpping S, Hildner M, Radke D, Beer M, et al. Lymphotoxin beta receptor signaling promotes tertiary lymphoid organogenesis in the aorta adventitia of aged ApoE-/- mice. J Exp Med. 2009 Jan 16;206(1):233-48.

43. Huan T, Zhang B, Wang Z, Joehanes R, Zhu J, Johnson AD, et al. A systems biology framework identifies molecular underpinnings of coronary heart disease. Arterioscler Thromb Vasc Biol. 2013 Jun;33(6):1427-34.

44. Mantani PT, Ljungcrantz I, Andersson L, Alm R, Hedblad B, Björkbacka H, et al. Circulating CD40+ and CD86+ B Cell Subsets Demonstrate Opposing Associations With Risk of Stroke. Arterioscler Thromb Vasc Biol. 2014 Jan;34(1):211-8.

45. Hansson GK, Bondjers G, Bylock A, Hjalmarsson L. Ultrastructural studies on the localization of IgG in the aortic endothelium and subendothelial intima of atherosclerotic and nonatherosclerotic rabbits. Exp Mol Pathol. 1980 Dec;33(3):302-15.

46. Lewis MJ, Malik TH, Ehrenstein MR, Boyle JJ, Botto M, Haskard DO. Immunoglobulin M is required for protection against atherosclerosis in low-density lipoprotein receptor-deficient mice. Circulation. 2009 Aug 4;120(5):417-26.

47. Virella G, Virella I, Leman RB, Pryor MB, Lopes-Virella MF. Anti-oxidized low-density lipoprotein antibodies in patients with coronary heart disease and normal healthy volunteers. Int J Clin Lab Res. 1993;23(2):95-101.

48. Shaw PX, Hörkkö S, Tsimikas S, Chang MK, Palinski W, Silverman GJ, et al. Human-derived antioxidized LDL autoantibody blocks uptake of oxidized LDL by macrophages and localizes to atherosclerotic lesions in vivo. Arterioscler Thromb Vasc Biol. 2001 Aug;21(8):1333-9. 
49. Xu Q, Luef G, Weimann S, Gupta RS, Wolf H, Wick G. Staining of endothelial cells and macrophages in atherosclerotic lesions with human heat-shock protein-reactive antisera. Arterioscler Thromb J Vasc Biol Am Heart Assoc. 1993 Dec;13(12):1763-9.

50. Hulthe J. Antibodies to oxidized LDL in atherosclerosis development--clinical and animal studies. Clin Chim Acta Int J Clin Chem. 2004 Oct;348(1-2):1-8.

51. Tsimikas S, Brilakis ES, Lennon RJ, Miller ER, Witztum JL, McConnell JP, et al. Relationship of IgG and IgM autoantibodies to oxidized low density lipoprotein with coronary artery disease and cardiovascular events. J Lipid Res. 2007 Feb;48(2):425-33.

52. Carbone F, Nencioni A, Mach F, Vuilleumier N, Montecucco F. Evidence on the pathogenic role of auto-antibodies in acute cardiovascular diseases. Thromb Haemost. 2013 May;109(5):854-68.

53. Tinahones FJ, Gómez-Zumaquero JM, Garrido-Sánchez L, García-Fuentes E, Rojo-Martínez G, Esteva I, et al. Influence of age and sex on levels of anti-oxidized LDL antibodies and anti-LDL immune complexes in the general population. J Lipid Res. 2005 Mar;46(3):452-7.

54. Kyaw T, Tay C, Krishnamurthi S, Kanellakis P, Agrotis A, Tipping P, et al. B1a B lymphocytes are atheroprotective by secreting natural $\operatorname{IgM}$ that increases IgM deposits and reduces necrotic cores in atherosclerotic lesions. Circ Res. 2011 Sep 30;109(8):830-40.

55. Lopes-Virella MF, Hunt KJ, Baker NL, Virella G, Moritz T, VADT Investigators. The levels of MDALDL in circulating immune complexes predict myocardial infarction in the VADT study. Atherosclerosis. 2012 Oct;224(2):526-31.

56. Ravandi A, Boekholdt SM, Mallat Z, Talmud PJ, Kastelein JJP, Wareham NJ, et al. Relationship of IgG and IgM autoantibodies and immune complexes to oxidized LDL with markers of oxidation and inflammation and cardiovascular events: results from the EPIC-Norfolk Study. J Lipid Res. 2011 Oct;52(10):1829-36.

57. Peters MJL, van Halm VP, Voskuyl AE, Smulders YM, Boers M, Lems WF, et al. Does rheumatoid arthritis equal diabetes mellitus as an independent risk factor for cardiovascular disease? A prospective study. Arthritis Rheum. 2009 Nov 15;61(11):1571-9.

58. Skaggs BJ, Hahn BH, McMahon M. Accelerated atherosclerosis in patients with SLE--mechanisms and management. Nat Rev Rheumatol. 2012 Apr;8(4):214-23.

59. Wada Y, Kuroda T, Murasawa A, Tanabe N, Nakano M, Gejyo F. Autoantibodies against oxidized lowdensity lipoprotein (LDL) and carotid atherosclerosis in patients with rheumatoid arthritis. Clin Exp Rheumatol. 2005 Aug;23(4):482-6.

60. Peters MJL, van Halm VP, Nurmohamed MT, Damoiseaux J, Tervaert JWC, Twisk JWR, et al. Relations between autoantibodies against oxidized low-density lipoprotein, inflammation, subclinical atherosclerosis, and cardiovascular disease in rheumatoid arthritis. J Rheumatol. 2008 Aug;35(8):14959 .

61. Ahmed HMMS, Youssef M, Mosaad YM. Antibodies against oxidized low-density lipoprotein are associated with subclinical atherosclerosis in recent-onset rheumatoid arthritis. Clin Rheumatol. 2010 Nov;29(11):1237-43.

62. Kiani AN, Vogel-Claussen J, Arbab-Zadeh A, Magder LS, Lima J, Petri M. Semiquantified noncalcified coronary plaque in systemic lupus erythematosus. J Rheumatol. 2012 Dec;39(12):2286-93. 
63. Wang J, Cheng X, Xiang M-X, Alanne-Kinnunen M, Wang J-A, Chen H, et al. IgE stimulates human and mouse arterial cell apoptosis and cytokine expression and promotes atherogenesis in Apoe-/- mice. J Clin Invest. 2011 Sep;121(9):3564-77.

64. Major AS, Fazio S, Linton MF. B-lymphocyte deficiency increases atherosclerosis in LDL receptor-null mice. Arterioscler Thromb Vasc Biol. 2002 Nov 1;22(11):1892-8.

65. Caligiuri G, Nicoletti A, Poirier B, Hansson GK. Protective immunity against atherosclerosis carried by B cells of hypercholesterolemic mice. J Clin Invest. 2002 Mar;109(6):745-53.

66. Ait-Oufella H, Herbin O, Bouaziz J-D, Binder CJ, Uyttenhove C, Laurans L, et al. B cell depletion reduces the development of atherosclerosis in mice. J Exp Med. 2010 Aug 2;207(8):1579-87.

67. Kyaw T, Tay C, Khan A, Dumouchel V, Cao A, To K, et al. Conventional B2 B cell depletion ameliorates whereas its adoptive transfer aggravates atherosclerosis. J Immunol Baltim Md 1950. 2010 Oct 1;185(7):4410-9.

68. Sage AP, Tsiantoulas D, Baker L, Harrison J, Masters L, Murphy D, et al. BAFF receptor deficiency reduces the development of atherosclerosis in mice--brief report. Arterioscler Thromb Vasc Biol. 2012 Jul;32(7):1573-6.

69. Kyaw T, Tay C, Hosseini H, Kanellakis P, Gadowski T, MacKay F, et al. Depletion of B2 but not B1a B cells in BAFF receptor-deficient ApoE mice attenuates atherosclerosis by potently ameliorating arterial inflammation. PloS One. 2012;7(1):e29371.

70. Doran AC, Lipinski MJ, Oldham SN, Garmey JC, Campbell KA, Skaflen MD, et al. B-cell aortic homing and atheroprotection depend on Id3. Circ Res. 2012 Jan 6;110(1):e1-12.

71. Wigren M, Kolbus D, Dunér P, Ljungcrantz I, Söderberg I, Björkbacka H, et al. Evidence for a role of regulatory $\mathrm{T}$ cells in mediating the atheroprotective effect of apolipoprotein B peptide vaccine. $\mathrm{J}$ Intern Med. 2011 May;269(5):546-56.

72. Schiopu A, Frendéus B, Jansson B, Söderberg I, Ljungcrantz I, Araya Z, et al. Recombinant antibodies to an oxidized low-density lipoprotein epitope induce rapid regression of atherosclerosis in apobec-1(-/)/low-density lipoprotein receptor(-/-) mice. J Am Coll Cardiol. 2007 Dec 11;50(24):2313-8.

73. Burut DFP, Karim Y, Ferns GAA. The role of immune complexes in atherogenesis. Angiology. 2010 Oct;61(7):679-89.

74. Chyu K-Y, Nilsson J, Shah PK. Immune Mechanisms in Atherosclerosis and Potential for an Atherosclerosis Vaccine. Discov Med. 2011 May 11;11(60):403-12.

75. Schwab I, Nimmerjahn F. Intravenous immunoglobulin therapy: how does IgG modulate the immune system? Nat Rev Immunol. 2013 Mar;13(3):176-89.

76. Ephrem A, Chamat S, Miquel C, Fisson S, Mouthon L, Caligiuri G, et al. Expansion of CD4+CD25+ regulatory $\mathrm{T}$ cells by intravenous immunoglobulin: a critical factor in controlling experimental autoimmune encephalomyelitis. Blood. 2008 Jan 15;111(2):715-22.

77. Fredrikson GN, Söderberg I, Lindholm M, Dimayuga P, Chyu K-Y, Shah PK, et al. Inhibition of atherosclerosis in apoE-null mice by immunization with apoB-100 peptide sequences. Arterioscler Thromb Vasc Biol. 2003 May 1;23(5):879-84. 
78. Chyu K-Y, Zhao X, Reyes OS, Babbidge SM, Dimayuga PC, Yano J, et al. Immunization using an Apo B-100 related epitope reduces atherosclerosis and plaque inflammation in hypercholesterolemic apo E (I-) mice. Biochem Biophys Res Commun. 2005 Dec 30;338(4):1982-9.

79. Klingenberg R, Lebens M, Hermansson A, Fredrikson GN, Strodthoff D, Rudling M, et al. Intranasal immunization with an apolipoprotein B-100 fusion protein induces antigen-specific regulatory $\mathrm{T}$ cells and reduces atherosclerosis. Arterioscler Thromb Vasc Biol. 2010 May;30(5):946-52.

80. Herbin O, Ait-Oufella H, Yu W, Fredrikson GN, Aubier B, Perez N, et al. Regulatory T-cell response to apolipoprotein B100-derived peptides reduces the development and progression of atherosclerosis in mice. Arterioscler Thromb Vasc Biol. 2012 Mar;32(3):605-12.

81. Xu Q, Dietrich H, Steiner HJ, Gown AM, Schoel B, Mikuz G, et al. Induction of arteriosclerosis in normocholesterolemic rabbits by immunization with heat shock protein 65. Arterioscler Thromb J Vasc Biol Am Heart Assoc. 1992 Jul;12(7):789-99.

82. George J, Shoenfeld Y, Afek A, Gilburd B, Keren P, Shaish A, et al. Enhanced fatty streak formation in C57BL/6J mice by immunization with heat shock protein-65. Arterioscler Thromb Vasc Biol. 1999 Mar;19(3):505-10.

83. Afek A, George J, Gilburd B, Rauova L, Goldberg I, Kopolovic J, et al. Immunization of low-density lipoprotein receptor deficient (LDL-RD) mice with heat shock protein 65 (HSP-65) promotes early atherosclerosis. J Autoimmun. 2000 Mar;14(2):115-21.

84. Harats D, Yacov N, Gilburd B, Shoenfeld Y, George J. Oral tolerance with heat shock protein 65 attenuates Mycobacterium tuberculosis-induced and high-fat-diet-driven atherosclerotic lesions. J Am Coll Cardiol. 2002 Oct 2;40(7):1333-8.

85. Maron R, Sukhova G, Faria A-M, Hoffmann E, Mach F, Libby P, et al. Mucosal administration of heat shock protein-65 decreases atherosclerosis and inflammation in aortic arch of low-density lipoprotein receptor-deficient mice. Circulation. 2002 Sep 24;106(13):1708-15.

86. Klingenberg R, Ketelhuth DFJ, Strodthoff D, Gregori S, Hansson GK. Subcutaneous immunization with heat shock protein-65 reduces atherosclerosis in Apoe ${ }^{-}{ }^{-}$mice. Immunobiology. 2012 May;217(5):5407.

87. George J, Afek A, Gilburd B, Blank M, Levy Y, Aron-Maor A, et al. Induction of early atherosclerosis in LDL-receptor-deficient mice immunized with beta2-glycoprotein I. Circulation. 1998 Sep 15;98(11):1108-15.

88. Hörkkö S, Bird DA, Miller E, Itabe H, Leitinger N, Subbanagounder G, et al. Monoclonal autoantibodies specific for oxidized phospholipids or oxidized phospholipid-protein adducts inhibit macrophage uptake of oxidized low-density lipoproteins. J Clin Invest. 1999 Jan;103(1):117-28.

89. Binder CJ, Hartvigsen K, Chang M-K, Miller M, Broide D, Palinski W, et al. IL-5 links adaptive and natural immunity specific for epitopes of oxidized LDL and protects from atherosclerosis. J Clin Invest. 2004 Aug;114(3):427-37.

90. Boyle JJ, Christou I, Iqbal MB, Nguyen AT, Leung VWY, Evans PC, et al. Solid-phase immunoglobulins $\operatorname{IgG}$ and IgM activate macrophages with solid-phase IgM acting via a novel scavenger receptor a pathway. Am J Pathol. 2012 Jul;181(1):347-61.

91. Smith KGC, Clatworthy MR. FcgammaRIIB in autoimmunity and infection: evolutionary and therapeutic implications. Nat Rev Immunol. 2010 May;10(5):328-43. 
92. Kelly JA, Griffin ME, Fava RA, Wood SG, Bessette KA, Miller ER, et al. Inhibition of arterial lesion progression in CD16-deficient mice: evidence for altered immunity and the role of IL-10. Cardiovasc Res. 2010 Jan 1;85(1):224-31.

93. Ng HP, Burris RL, Nagarajan S. Attenuated atherosclerotic lesions in apoE-Fcy-chain-deficient hyperlipidemic mouse model is associated with inhibition of Th17 cells and promotion of regulatory $\mathrm{T}$ cells. J Immunol Baltim Md 1950. 2011 Dec 1;187(11):6082-93.

94. Mendez-Fernandez YV, Stevenson BG, Diehl CJ, Braun NA, Wade NS, Covarrubias R, et al. The inhibitory Fc $\gamma \mathrm{RIIb}$ modulates the inflammatory response and influences atherosclerosis in male apoE(-/) mice. Atherosclerosis. 2011 Jan;214(1):73-80.

95. Virella G, Lopes-Virella MF. Atherogenesis and the humoral immune response to modified lipoproteins. Atherosclerosis. 2008 Oct;200(2):239-46.

96. Moulin V, Andris F, Thielemans K, Maliszewski C, Urbain J, Moser M. B lymphocytes regulate dendritic cell (DC) function in vivo: increased interleukin 12 production by DCs from B cell-deficient mice results in T helper cell type 1 deviation. J Exp Med. 2000 Aug 21;192(4):475-82.

97. Zietara N, Łyszkiewicz M, Puchałka J, Pei G, Gutierrez MG, Lienenklaus S, et al. Immunoglobulins drive terminal maturation of splenic dendritic cells. Proc Natl Acad Sci U S A. 2013 Feb 5;110(6):22827.

98. Lund FE, Randall TD. Effector and regulatory B cells: modulators of CD4+ T cell immunity. Nat Rev Immunol. 2010 Apr;10(4):236-47.

99. Karper JC, de Jager SCA, Ewing MM, de Vries MR, Bot I, van Santbrink PJ, et al. An Unexpected Intriguing Effect of Toll-Like Receptor Regulator RP105 (CD180) on Atherosclerosis Formation With Alterations on B-Cell Activation. Arterioscler Thromb Vasc Biol. 2013 Oct 10;

100. Opata MM, Ye Z, Hollifield M, Garvy BA. B Cell Production of Tumor Necrosis Factor in Response to Pneumocystis murina Infection in Mice. Infect Immun. 2013 Nov;81(11):4252-60.

101. Turpeinen H, Raitoharju E, Oksanen A, Oksala N, Levula M, Lyytikäinen L-P, et al. Proprotein convertases in human atherosclerotic plaques: the overexpression of FURIN and its substrate cytokines BAFF and APRIL. Atherosclerosis. 2011 Dec;219(2):799-806. 


\section{Figure Legend}

A. B cell development and subsets. B1 cells develop primarily from fetal liver and self-maintain in the adult. B1 cells are the source of natural IgM antibodies that target antigens such as oxidized phospholipids. B2 cells develop from adult bone marrow stem cells and undergo a series of differentiation steps in the bone marrow, then leave as immature/transitional B cells and further differentiate into either marginal zone or follicular B cells in the spleen. B2 cell activation leads to short-lived plasma cell differentiation or, in the case of $\mathrm{T}$ cell dependent responses, germinal centre formation, which results in affinity maturation of the B cell clone and formation of memory B cells and long-lived plasma cells, which can persist in specific bone marrow niches until ntigen reencounter. B. B cell regulation of atherosclerosis. Natural antibodies and other IgM targeting oxLDL, primarily but not exclusively from B1 cells, is thought to be atheroprotective. The potential pro-atherogenic functions of B2 cells include production of IgG2 antibodies that activate macrophages via Fc receptors, activation of pro-atherogenic Th1 CD4 T cells, or production of proinflammatory T cells. B cells may act remotely from peripheral lymphoid organs or locally from the adventitia and atherosclerotic plaque. 
A

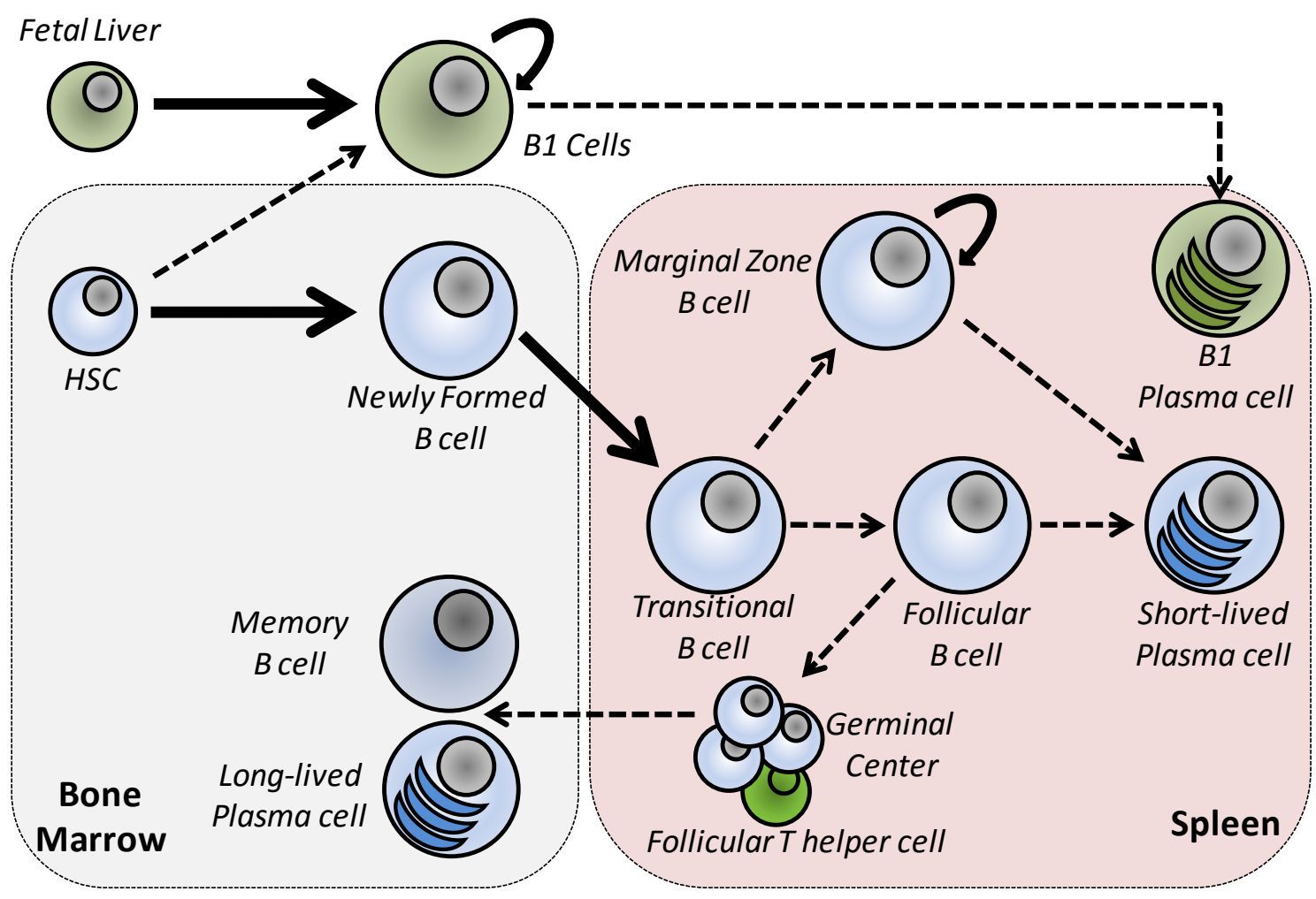

B

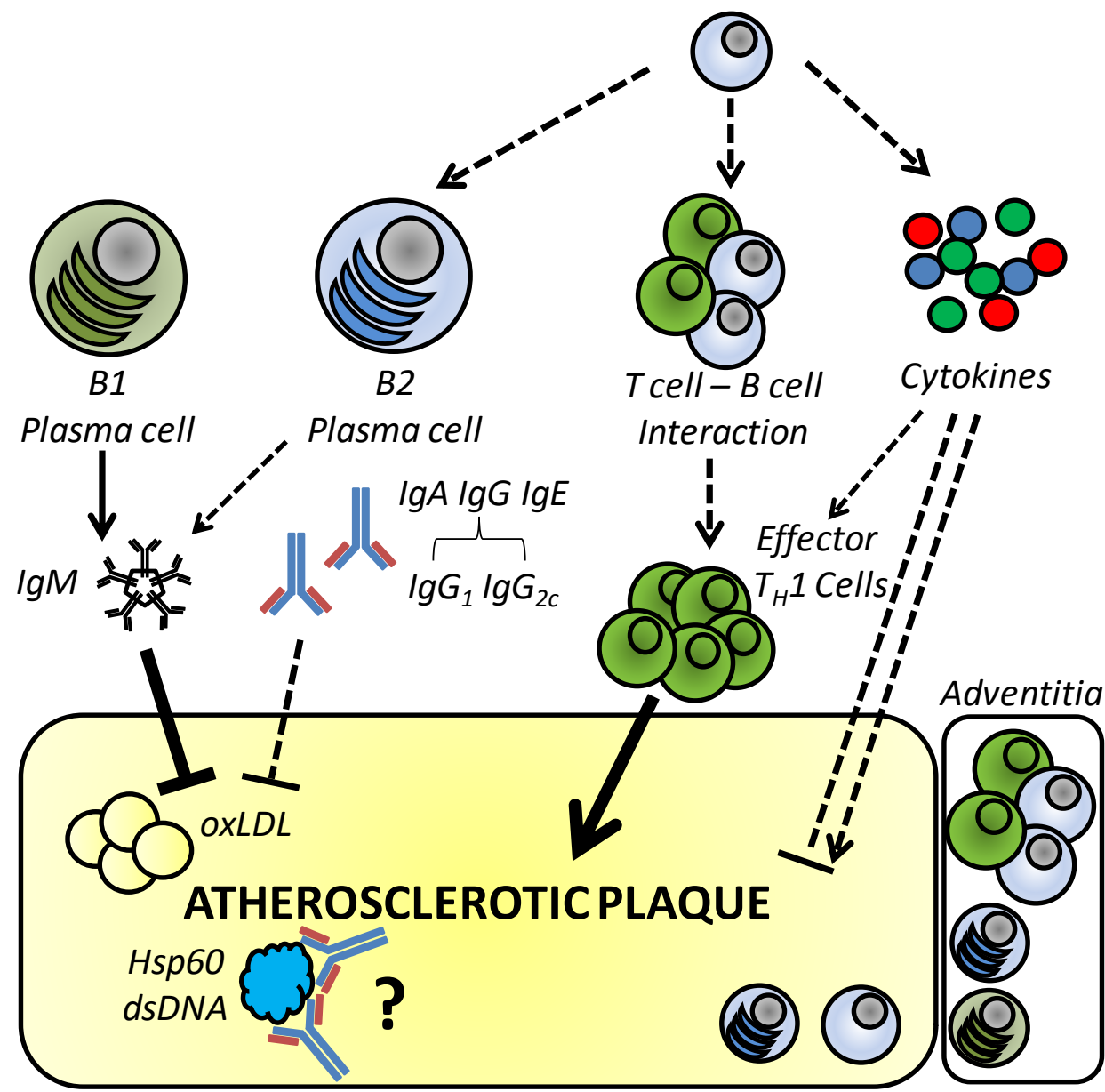

